\title{
PERSONALIZED ONLINE REFLECTIVE DELIBERATIONS: NO SIGNIFICANT DIFFERENCES ACROSS INSTITUTION TYPE
}

\author{
Anita Chadha, University of Houston, Downtown
}

\begin{abstract}
This research contributes to knowledge about the effectiveness of online deliberations as an innovative means for providing online education. Using a mixed methods approach, student peer exchanges were analyzed on a collaborative website structured around interactive weekly discussions in politics and offered across three types of institutions: a four-year public university, a four-year private university, and a community college. Findings show that despite differences in institution type, the 81 students responded and personalized their discussions with academic reflectivity across class types in their peer discussions. This study finds that interactive discussion forums are a best practice for offering pedagogical content in an online environment and may be used across any discipline or class type whether it is a face-to-face, hybrid, or fully online.

Keywords: classroom innovation, online best practices, educational best practices, online teaching and learning

\section{INTRODUCTION}

With the physical classroom losing its monopoly in higher education and the Internet making online learning possible, educators are seeking ways to offer online courses that are academically robust and that enhance and improve student learning outcomes (Allen \& Seaman, 2015; Farinella, Hobbs, Weeks, 2000; Pape, 2010). Online peer deliberations are pedagogically ideal for this endeavor (Bozanta \& Mardikyan, 2017; Chadha, 2017b; Chu, Capio, van Aalst, \& Cheng, 2017; Pappas, 2014; Pukdesree, 2017). When students learn through an egalitarian process (like deliberations), they generate, challenge, reflect upon, and defend ideas, thereby constructing meaning and enhancing their knowledge through these interactions no matter where they are geographically enrolled (Chu et al., 2017; Dixson, 2010; Paul \& Elder, 2012; Pukdesree, 2017; Rountree, 1995). Student peer deliberations offer a learning experience that is qualitatively different from the usual teacher-studentinteractions,

as Englund (2006) found: "within deliberative communication, each participant takes a stand by listening, deliberating, and evaluating their own while there is a collective effort to seek information learning from each other even when they can (dis) agree or challenge each other's positions" (p. 503). Several researchers found that peer interaction and course engagement have positive effects on collaborative learning (Bozanta \& Mardikyan, 2017; Chadha, 2017b; Chu et al., 2017).

The advantage of online peer interactive learning through discussions is that peers are in similar positions and can share and identify experiences with each other without being in positions of authority (Boud, Cohen, \& Sampson, 2014). In addition, these spaces provide for equal participation for everyone with regard to their personal characteristics as these are masked online (Herring, 1993). These interactive deliberations are not just talk for the sake of talking; they involve critical reflection when responding to each other.
\end{abstract}


Students may personalize their experiences when responding while being open to understanding different perspectives (Chadha, 2017b; Englund, 2006). Because of these factors, the use of online deliberative pedagogical processes is considered a best practice as they enhance learning through personalized interactions and advance academic dialogue as a worthy goal in online education (Cho, Ahmed, Keum, Choi, \& Lee, 2018; Evans, Steele, Robertson, \& Dyer, 2017; Mooney \& Lang, 2018).

The central aim of this research was to analyze one semester of peer student discussions in an online collaborative web space designed with interactivity in mind in order to answer the following research question: Would a collaborative online space created for academic deliberation offer a platform for students to personalize their engagement with academic reflectivity across different types of institutions? In order to explore this question, an interactive online subscription-based website was designed that was accessible only to those who had signed human subject consent forms or had obtained parental consent. The subscription website URL was from a ning.com site (http:// americanpoliticscollspring17.ning.com/). On this website, professors took turns posting questions of the week. During the semester-long project, students would post and respond to their peers across the institutions to the same question posted weekly by one professor with a new question posted each week. The quality of the deliberative response to the instructor's questions was assessed not based on frequency of posts but rather on the thoughtfulness of the posts and the use of academic works such as class texts and academic documents. Comparisons across institution type were possible as the professors discussed before the semester started the similarities of their courses' subject material and agreed to a standardized list of instructions for designing their syllabi.

This study contributes to the field of online education by showing online deliberations to be an effective best practice for engaging students across varying types of institutions. This is especially true given the push for more technologically innovative, and effective, educational tools to be incorporated into course offerings. This study is particularly important for full- and part-time faculty members teaching face-to-face, hybrid, and online courses across a range of disciplines. In addition, the results are relevant for those interested in providing effective online courses that are educationally vigorous, as well as for IT developers and university administrators addressing the changing nature of their student clientele.

\section{LITERATURE REVIEW}

Deliberation is a process where students study an issue, consider alternative solutions and potential consequences, and develop critical reasoning skills about an issue. In deliberations, students consider the arguments of others and question and reconsider their own viewpoints by engaging with their peers even when it places their own views in doubt (Boud et al., 2014; Eveland, Shah, \& Kwak, 2003; Kenski \& Stroud, 2006; Stitzlein, 2010). When deliberating with peers, students carefully listen to the ideas and arguments expressed by others and participate in interactive dialogue asking insightful and respectful questions that challenge participants' viewpoints (Bozanta \& Mardikyan, 2017; Chu et al., 2017). This type of "structured academic controversy" is one way of engaging students about contentious issues (Guttman, 2000, p. 75).

The literature is expansive on the effectiveness of using collaborative activities that involve students giving and receiving feedback while accounting for their views (Boud et al., 2014; Cho et al., 2018; Evans et al., 2017; Eveland et al., 2003; Kenski \& Stroud, 2006; Mooney \& Lang, 2018). Well-designed deliberations not only facilitate meaningful cooperation among their participants but also produce a number of tangible outcomes. Specifically, they may lead to increased political participation, positive academic outcomes (Anderson, 2003; Chadha, 2017a; Chadha, 2017c; Eveland et al., 2003; Kenski \& Stroud, 2006; Levy, 2008; Merryfield, 2001; Moy \& Gastil, 2006; Roblyer \& Wiencke, 2004), growth in knowledge and efficacy (Eveland et al., 2003; Kenski \& Stroud, 2006; Moy \& Gastil, 2006), and dramatic student gains in conceptual and problem-solving test scores when compared with a traditional lecture format (Hake, 1998). In addition, students have been shown to value interactive ways of learning (Levy, 2008), and they have reported higher levels of satisfaction with their learning experience (Swan, 2002).

With regard to the deliberative process itself, research has shown its use in educational contexts is beneficial for a number of reasons. First, it promotes 
identification with other student peers. In explaining their own perspectives to others, students find ways to identify with others' experiences (Hostetter \& Busch, 2013; Mandernach, 2009; Stitzlein, 2010). They may offer personal features or experiences they share in common, such as being deployed by the military or being single parents themselves. Identifying with peers through personalized experiences provides greater clarity of perspective (Boud et al., 2014).

Second, deliberation promotes student reflectivity. Students who systematically reflect on their experiences are more likely to seek out alternative perspectives and identify with and question their peers using commonalities of experience with deliberative academic thought (Pamental, 1998). Cole, Shelley, \& Swartz, (2014) also found, "When students explain it and they have a way to make it extremely relevant to your life and show you how this actually relates to you specifically, that can make the material really exciting" (p. 1). This is not to say that all participants agree; they disagree, challenge, even push each other to consider and reconsider issues (Stitzlein, 2010). Coupled with the richness of personal, individualized sharing of experiences, students develop skills to handle and resolve disagreements arising from conflicting points of view (Gurin, Nagda, \& Lopez, 2004; Zúñiga, Williams, \& Berger, 2005).

While deliberative processes have become an earnest goal for educators in general, its applicability in the virtual classroom (i.e., online or hybrid courses) is also promising. A growing body of research suggests that overall student achievement increases when students engage with peers in an online deliberative dialogue (Bozanta \& Mardikyan, 2017; Chu et al., 2017; Pappas, 2014; Pukdesree, 2017). In particular, web-based interactive tools not only prompt students to reflect on their learning, but also, they are effective in integrative learning (Bixler, 2007; Chadha, 2017c; Chang, 2007; Chung, Chung, \& Severance, 1999; Cook, Dupras, Thompson, \& Pankratz, 2005; Crippen \& Earl, 2007; Saito \& Miwa, 2007; Shen, Lee, \& Tsai, 2007; Wang Wang, Wang, \& Huang, 2006). In addition, personalized deliberations foster a general appreciation of peer perspectives when involved in online discussions (Cho et al., 2018; Evans et al., 2017; Mooney \& Lang, 2018;
Stitzlein, 2010). And, in fact, students themselves find collaborative online learning forums to be greatly beneficial to their own learning experiences (Pukdesree, 2017).

Overall-and similar to Chickering and Gamson's (1987) seven principles for good practice in undergraduate education (see also Dayton \& Vaughn, 2007; Meyer, 2003; Newlin \& Wang, 2002) - online discussions: (a) encourage studentpeer/faculty contact, (b) encourage cooperation among students, (c) encourage active learning, (d) provide prompt feedback, (e) emphasize time on task, (f) communicate high expectations, and (g) respect diverse talents and ways of learning as guidelines for effective teaching and learning.

In examining the effectiveness of online teaching when compared to traditional face-to-face teaching, researchers have found that online designs using interactive deliberative forums perform similar duties as face-to-face deliberations while also promoting positive civic knowledge, attitudes, and/or behaviors (Chadha, 2017b; Delli \& Keeter, 1996; Ellis, Goodyear, Prosser, \& O'Hara, 2006; Keramidas, 2012). And numerous studies over the years confirm that retention rates are on par with face-to-face modes with no significant differences in their course outcomes (Baek, Wojcieszak, \& Delli Carpini, 2012; Chung \& Han, 2013; Ellis et al., 2006; Eom \& Ashill, 2016; Jaggars, 2014; Keramidas, 2012; Pape, 2010;Wladis, Conway, \& Hachey, 2015).

Compared with face-to-face deliberative techniques for engaging students, deliberation in an online format has additional characteristics that promote student participation, namely, (a) student anonymity, (b) gender equalization, and (c) asynchronicity (i.e., students may participate at a time convenient for them). With regard to anonymity, students have no knowledge about a participant's race, ethnicity, religion, course level, or mode of instruction. This eliminates an individual's status cues allowing for thoughtful exchanges among peers on a relatively even playing field (Caspi et al., 2008; Herring, 1993; Kiesler, Siegel, \& McGuire, 1984). Studies confirm that online interactive deliberations offer a space that is relatively neutral for its acceptance of differences among peers across all racial/ethnic groups (Hardy \& Scheufele, 2002; Zúñiga et al., 2005). And as Herring (1993) concludes, interactive learning 
"also provide[s] for the possibility that traditionally lower-status individuals can take part on the same terms as others that is, with anonymity, with the emphasis being on the content, and not on the form of the message or the identity of the sender" (p. 1). Online deliberations also allow time for students to reflect before interacting without their peers' personal characteristics (such as race, gender, or their region of the country) being a factor (Herring, 1993; Stitzlein, 2010). Moreover, with their identities concealed, peers are often more open, frank, expressive, and curious when debating and challenging each other or when sharing and discussing sensitive issues (Saunders, 1992). These discussion exchanges are a constructive means by which to collaborate and engage students in higherorder thinking based on the message and not on the sender's characteristics (Faraj, Jarvenpaa, \& Majchrzak, 2011; Meyer, 2003)

The anonymity of online interactions also helps to equalize gender. As Rovai and Baker (2005) found, "females felt more connected to other students in their courses, felt that their online learning experiences were more aligned to their educational values and goals, and perceived they learned more than their male peers" (p. 31). Equalizing effects also have been identified by other researchers who found that women participated at rates equal to their male peers because they could occupy the nonhierarchical space of online learning at their discretion, on their own terms, and at their own pace (Bukovchik, R., Van Vechten, R. B., \& Chadha, 2013; Graddol \& Swann, 1989; Kiesler et al., 1984; Wolfe 2000). With students remaining largely anonymous across gender differentials, they challenge diverse viewpoints, developing an awareness of alternative perspectives and a deeper appreciation of minority rights (Bukovchik et al., 2013; Chadha, 2017b; Guttman, 2000).

Finally, online interactions are often asynchronous. Asynchrony means that students can post responses at any time allowing them to engage with issues and material more meaningfully. This is because students have time to think critically through arguments, evaluate evidence, draw conclusions, reflect, and reconsider and reestablish their positions (Chadha, 2017a; Hamann, Pollock, \& Wilson, 2009; Yoo \& Huang, 2013). In using time and space at their discretion, they have ownership of discussions, which sharpens their perspectives
(Garrison, Anderson, \& Archer, 2003; Paul \& Elder, 2012).

Asynchronistic means are known to aid in higher-order reasoning as well (Avery et al., 2004). Specifically, it encourages critical reflection and dialogue in a space and time that is suitable for each student. It also allows ample time for students to consider all sides of an issue before offering their own educated response. Researchers find that asynchronous interactive activities cultivate rapport and collaboration among students and prompt thought-provoking questions as well as dynamic interactions (Gayton \& McEwen, 2007).

Though online deliberative formats promote further student engagement through anonymity and a synchronicity, they are not without limitations. Foremost, learner isolation is a likely issue for online courses in general (Conrad \& Donaldson, 2004). In addressing issues of learner isolation online, researchers suggest that creating discussion forums and engaging students with peers is key to fostering learning and building a sense of community (Conrad \& Donaldson, 2004). Other researchers suggest offering both synchronous and asynchronous activities. The benefit of synchronous sessions is that they offer a sense of presence; however, this leads to the issue of inequality as not all students would be able to attend these sessions due to work or personal scheduling conflicts. Often, these are the very reasons a student would enroll in an online class in the first place, to avoid potential scheduling conflicts (Dixson, 2010; Kehrwald, 2008). This is especially true for students who are militarily deployed or on medical leave.

In addition, to offer educationally challenging courses in an online format, university IT departments need capabilities for training instructors on how to create academically challenging online courses and provide enough support for both instructors and students. Such concerns are of practical significance to university administrators, policy makers, and designers needing to create accessible online virtual spaces for educational purposes. Despite the limits of online formats, substantial evidence suggests that online learning is at least as effective as the traditional format and calls for more significant published research as the arenas of online education and teaching expand nationally and globally (Chadha, 2017a; Hamann, et al., 2009Lou, Abrami, 
\& d'Apollonia, 2001; Russell, 1999). In addition, an interactive instructional design is important for addressing the limits mentioned above (Eom \& Ashill, 2016; Pappas, 2014).

This study adds to the burgeoning body of research in online education by exploring the effectiveness of online deliberations as a pedagogical tool across three institution types (four-year public university, four-year private university, and community college). Of particular importance is the focus on different institution types because cross-institutional research related to the effectiveness of online learning is scarce (Jaggars, 2014). Finally, this study relied on a carefully designed online space that allowed opportunities for students enrolled at different universities/colleges to participate together on an equal footing.

\section{METHODS}

Prior to the start of the spring semester, three professors discussed the similarities of their courses' level, objectives, and subject material and agreed to offer an online collaboration across their three courses. The course goals were the same as well, lending to the compatibility of the collaboration. They agreed on a common set of assignments for the collaboration that included common instructions, a course grade, and the same minimum number words and postresponse requirements, which they added to their syllabus requirements. The three participating faculty members obtained human subject consent, met FERPA requirements on each campus, and prepared to offer an alternative project for those not consenting.

With the purpose and design of the online collaboration agreed upon, they designed a collaborative website with student peer interactivity in mind so the students would have time and space to think critically before responding (Boud, Cohen, \& Sampson, 2001; Herring, 1993; Paul \& Elder, 2012). This study analyzed the online peer interactions of the 81 students in an introductory political science course during a spring semester at a four-year public university, four-year private university, and a community college.

The analysis was conducted using a mixed methods approach that involved content analysis and testing through MANOVAs. Content analysis was chosen due to its frequent use by researchers to code qualitative discussion boards, which constitute a part of online instruction (Bukovchik et al., 2013; Chadha, 2017a; Hamann et al., 2009; Topping, 1996; Wilson, Pollock, \& Hamann, 2007). In finding a coding scheme that would be both comprehensive and would enable reliability in analyzing the material, the researchers developed their own measures for coding depending upon the study. Some researchers have employed a coding scheme by counting how many student statements were "in-depth" posts - that is, they added new critical ideas or evidence to the discussion - when responding to other students' postings directly or indirectly (Hamann et al., 2009; Pollock et al., 2011; Wilson et al., 2007). Another researcher developed a model to highlight several dimensions of the learning process: participation, interaction, social, cognitive, and metacognitive dimensions (Wickersham \& Dooley, 2006). For this study, a published index (Bukovchik et al., 2013; Chadha, 2016a; Chadha, 2016b) that related to student reflectivity among peers online, measured student reflectivity, and gauged the deliberative exchange of ideas among students using academic works within these discussions was used to analyze the 170 interactive responses among the 81 students.

Content analysis was then statistically tested using MANOVAs. These were used because, though all three classes were freshman-level courses on American politics, one of the class designations was at the 3000 level (even though it was the same subject as the other two classes). Therefore, the MANOVA tests statistically determined any differences between the independent groups of the differing levels of freshman classes. Pre- and posttest surveys about the nature of student online interactions from the semester added the student perspective.

\section{Comparability across Courses}

With the collaboration designed as a space for student interaction and the collaborative website designed with student peer interactivity in mind, instructors posed weekly questions for students across the institutions to discuss. Students were asked the same questions and required to respond to the weekly discussion questions posted by the instructors and also to respond to other students' posts to build a discussion-oriented online community. Typically, the students had the week to 
Table 1. Comparability of Course Collaboration

\begin{tabular}{|c|c|c|c|c|}
\hline Institution type & Four-year public university & Four-year private university & Community college & $\begin{array}{l}\text { Common collaborative } \\
\text { requirements }\end{array}$ \\
\hline Course name & American Capstone & American Politics & American Politics & \multirow{3}{*}{$\begin{array}{l}8 \text { posts and responses } \\
75 \text {-word minimum length } \\
\text { Grade in syllabus }\end{array}$} \\
\hline Course level & Freshman & Freshman & Freshman & \\
\hline No of students & 21 & 34 & 26 & \\
\hline
\end{tabular}

analyze and respond to the question or "the post." In order to build dialogue, the students were also required to respond to others" posts, which is "the response." All students would post and respond to the same question, which changed each week, thus creating a separate forum of discussion on a weekly basis. This exchange between instructor and student and student-to-student furthered personal interaction, investment in the website, and a sense of an online community. While instructors did not offer examples of posts or responses, they did emphasize that students take part consistently and reminded them of the ground rules when necessary. Students were also required to use a minimum length of 75 words, which is about four fully typed lines, in their posts and responses. Other than the word guidance and the requirement to respond and reply to the same number of discussion questions, no other directions were given to the students about how to interact or build a post or response. A grade was also assigned by each professor on the syllabus. A comparability of course collaboration is shown in Table 1.

The semester-long project virtually linked classes across three states and different time zones. A descriptive summary of campus participants appears in Table 1. During that time the professors monitored conversations for signs that students were abiding by the general rules of respect, decency, and civility, and talking to each other about any issues or concerns about the collaboration, but they generally refrained from participating in the discussion forums themselves. The instructors were mindful of the various pedagogical goals:

- increasing student interaction and participation;

- reinforcing lessons;
- holding students accountable for views;

- developing a better understanding of points of view;

- improving communication and analytical skills;

- articulating points;

- building civility, tolerance, and critical thinking;

- deepening a sense of identity; and

- expanding a sense of "community."

The Dependent Composite Variable: Academic Reflectivity.

With the collaboration being a means of interactivity among students, the dependent variable would measure evidence of academic reflectivity in student interactions. An academic reflectivity index using published research (Bukovchik et al., 2013; Chadha, 2016a; Chadha, 2016c) measured the thoughtful academic deliberation that took place in these online interactive discussions. The index would measure how reflective and/or deliberate the students were. Were they:

- thoughtful in their posts and responses,

- thinking critically,

- developing informed perspectives about civic issues,

- learning from each other,

- tying in ideas from classroom discussions or texts,

- referencing external web links or books,

- asking questions that required extensive discussion,

- interacting in a civilized way,

- providing posts or responses that were beyond grade requirements, and

- taking time to be thoughtful and deliberative in their discussions. 
If the students were not as reflective or thoughtful in their responses but were unreasonable, as when they made broad generalizations in a negative or derogatory way to others, they were not considered reflective. Measuring critical reflection in discussions required a thorough reading of each student's contribution and responses to other students' posts. Each response was coded for academic reflectivity.

\section{Operationalizing the Variables}

Six variables were coded for academic reflectivity.

1. To be reflective/ deliberative means that students had reflected, deliberated, or reconsidered their own views when they responded to questions or when they commented on other students' posts. They puzzled through problems or issues, questioned others, challenged others, or held them accountable for their views in a positive way. They thought about the question and responded with reflective, deliberate comments. A score of 1 or 0 was assigned for each of the following categories:

2. Civic roles. Were the students thoughtful citizens? Did they think about the questions posed and respond in ways that reflected a theoretical or practical application of American politics? Did they discuss civic issues such as the First Amendment or voting issues rather just mention them? Did they engage each other and not just agree or disagree with each other? Did they challenge or push one another to think in a civil way?

3. Classroom ideas or texts. In their responses did the students refer to ideas that they had read about in class or mention their professor's material or in-class discussions?

4. References or outside links. Did the students post or cite links to external websites when responding to questions, or did they refer to court cases that one might look up? Did they cite current events or media-related stories that might be looked up or located by another student? Did they post real links to other related sources?

5. Pose honest questions. Did the students actually ask one or more questions that enlarged the scopes of the discussions, questions that expanded discussions and not rhetorical ones that assumed answers?

6. Length. A scale of 1-3 was used: $1=a$ short response of usually 75 words or fewer, or up to four full lines of text; $2=$ a medium response, between five and nine lines of text; and $3=$ a long response, longer than ten lines of text.

One point was assigned to the first five variables. The sixth variable, length, had a range of points. The lowest possible score was one, while the most a student scored was eight. The total number of postings per student (example: student $\mathrm{X}$ posted six times a day, five days in a row) was not used as a measure toward increased learning as it was not the total number of posts and responses that were reflective, but rather the reflective score measured thoughtful understanding and contribution to a post or response.

\section{THE HYPOTHESES}

With the collaborative website designed with interactivity, and given the benefits online spaces provide for student identities, and their institutions hidden, and providing students with the time and space to evaluate posts and responses with academic intent before responding to peers, four hypotheses followed:

(H1), Students would respond to peers across the institutions, not just their own classes, with academic reflectivity.

(H2). Students would identify with others across the institutions by personalizing responses (for instance, "I know what you mean ..." or "Like you, I ...") with academic reflectivity.

(H3). Students would post and respond across gender differentials at the institutions with academic reflectivity.

(H4). Students would interact with academic reflectivity across the differing institutions.

\section{RESULTS AND DISCUSSION}

Based on the four hypotheses, MANOVAs were used to compare the three institution reflectivity scores. First, Table 2 displays the mean and standard error scores of reflectiveness by students responding to each other across the three institutions. Following the mean and standard error results, MANOVAs were performed.

The first MANOVA tested for academic reflectivity score variability as a function of students responding across classes. The second 


\begin{tabular}{|c|c|c|c|c|}
\hline \multicolumn{5}{|c|}{$\begin{array}{l}\text { Table 2. Mean and Standard Error Scores of Reflectivity by Students } \\
\text { Responding to Each Other Across the Three Institutions }\end{array}$} \\
\hline (I) IRespond & (J) IRespond & $\begin{array}{c}\text { Mean Difference } \\
\text { (I-J) }\end{array}$ & Std. Error & Sig. \\
\hline \multirow[t]{5}{*}{1.00} & 2.00 & .05 & .031 & .114 \\
\hline & 3.00 & .07 & .056 & .232 \\
\hline & 4.00 & $.43^{*}$ & .081 & .000 \\
\hline & 5.00 & $.43^{*}$ & .127 & .001 \\
\hline & 7.00 & $.43^{*}$ & .127 & .001 \\
\hline
\end{tabular}

\begin{tabular}{|c|c|c|c|c|c|c|}
\hline \multicolumn{2}{|r|}{ Effect } & Value & $F$ & Hypothesis df & Error df & Sig. \\
\hline \multirow[t]{4}{*}{ Gender } & Pillai's trace & .044 & $3.103 \mathrm{~b}$ & 2.000 & 134.000 & .048 \\
\hline & Wilks' lambda & .956 & $3.103 \mathrm{~b}$ & 2.000 & 134.000 & .048 \\
\hline & Hotelling's trace & .046 & $3.103 \mathrm{~b}$ & 2.000 & 134.000 & .048 \\
\hline & \begin{tabular}{|l|} 
Roy's largest root \\
\end{tabular} & .046 & $3.103 \mathrm{~b}$ & 2.000 & 134.000 & .048 \\
\hline \multirow{4}{*}{$\begin{array}{l}\text { Identify across } \\
\text { classes }\end{array}$} & Pillai's trace & .056 & $3.992 b$ & 2.000 & 134.000 & .021 \\
\hline & Wilks' lambda & .944 & $3.992 b$ & 2.000 & 134.000 & .021 \\
\hline & Hotelling's Trace & .060 & $3.992 b$ & 2.000 & 134.000 & .021 \\
\hline & Roy's largest root & .060 & $3.992 b$ & 2.000 & 134.000 & .021 \\
\hline \multirow{4}{*}{$\begin{array}{l}\text { Respond across } \\
\text { classes }\end{array}$} & Pillai's trace & .078 & 2.728 & 4.000 & 270.000 & .030 \\
\hline & Wilks' lambda & .923 & $2.756 \mathrm{~b}$ & 4.000 & 268.000 & .028 \\
\hline & Hotelling's trace & .084 & 2.784 & 4.000 & 266.000 & .027 \\
\hline & Roy's largest root & .081 & $5.453 \mathrm{c}$ & 2.000 & 135.000 & .005 \\
\hline \multirow{4}{*}{$\begin{array}{c}\text { Interact across } \\
\text { classes }\end{array}$} & Pillai's trace & .080 & 1.873 & 6.000 & 270.000 & .086 \\
\hline & Wilks' lambda & .920 & $1.893 \mathrm{~b}$ & 6.000 & 268.000 & .082 \\
\hline & Hotelling's trace & .086 & 1.912 & 6.000 & 266.000 & .079 \\
\hline & Roy's largest root & .083 & $3.728 \mathrm{c}$ & 3.000 & 135.000 & .013 \\
\hline
\end{tabular}

Table 4. LSD Post-hoc Significance of Test Differences in Mean Scores for the Four Comparisons Across Institutions by Reflectivity

\begin{tabular}{|c|c|c|c|c|c|c|}
\hline \multirow{2}{*}{\multicolumn{2}{|c|}{ Dependent variable }} & \multirow{2}{*}{$\begin{array}{c}\text { Mean Difference } \\
\text { (I-J) }\end{array}$} & \multirow[b]{2}{*}{ Std. Error } & \multirow{2}{*}{$\begin{array}{l}\text { Sig. } \\
\text { Lower } \\
\text { Bound }\end{array}$} & \multicolumn{2}{|c|}{ 95\% Confidence Interval } \\
\hline & & & & & Upper Bound & \\
\hline \multirow[t]{6}{*}{ Reflective } & \multirow[t]{6}{*}{ LSD } & .06 & .079 & .413 & -.09 & .22 \\
\hline & & $-.51^{*}$ & .197 & .011 & -.90 & -.12 \\
\hline & & -.06 & .079 & .413 & -.22 & .09 \\
\hline & & $-.57^{*}$ & .208 & .007 & -.98 & -.16 \\
\hline & & $.51^{\star}$ & .197 & .011 & .12 & .90 \\
\hline & & $.57^{*}$ & .208 & .007 & .16 & .98 \\
\hline
\end{tabular}


MANOVA tested for students identifying with each other across institutions with academic reflectivity. The third MANOVA tested for students responding across their gender with academic reflectivity across institutions. And the fourth MANOVA tested for reflectivity scores based on students interacting with each other across classes with academic reflectivity. Statistically significant multivariate $\mathrm{F}$ tests were achieved for each of the four hypotheses across the varied institutions as provided in Table 3 across Pillai's trace, Wilks' lambda, Hotelling's trace, and Roy's largest root.

Significant evidence provides proof that interactive discussions among students, across geographically distant states, about common and often challenging issues with a diverse student body deepened their understanding of issues and interconnectedness not only as members of a larger online class, but also as part of a larger civic community. With the significance of all the MANOVAs, follow-up univariate ANOVAs showed that each of the four univariate scores, that of gender, $F(1,135)=1.268, p<.262$, students identifying with each other across classes, $F(1$, $135)=.798, p<.373$, students interacting with each other across classes, $F(3,135)=.969, p<$ .063 , and students responding to with each other across classes, $F(2,135)=5.281, p<.006$, were statistically significant. With significance in multivariate and univariate tests, students enrolled in a four-year public university, a four-year private university, or a community college performed with reflectivity across each of the four hypotheses. In other words, students identified, responded, and interacted across the institutions without gender differentials. LSD post hoc comparisons followed and were significant as reported in Table 4.

Implications for these significant results are fruitful for educators in any discipline, for policy makers, and for online designers who seek to design successful academic courses. A carefully designed and managed web space with interactive components can promote engaged and reflective online discussions across varied institutional types. These are important findings as online discussions link students across diverse characteristics such as race, gender, religion, ethnic profile, and course level. This highly varied membership challenges students with various viewpoints and they develop an awareness of alternative points of view, a more reflective understanding of collective problems, and an appreciation of majority and minority rights (Guttman, 2000).

The student perspective from the end-ofsemester evaluations across the institutions further supports these findings as shown in Table 5. Openand closed-ended questions confirm that students were engaged in reflective deliberations with each other and they appreciated the interactive collaboration. In response to an open-ended question about what they thought about the collaboration, they noted that they were "open to listening to each other" and "appreciated the diversity in perspectives." In addition, 70\% of the students said that they related to their peers, made meaningful connections with them, and felt they belonged to a "political community." Over half of the students visited the interactive website for reasons other than making their required posts and responses.

When asked to describe their experience, their responses were overwhelmingly positive. They were more open to listening to opposing views and that they appreciated interacting with others. Their few-word reactions included: "Brilliant," "Great experience," "really different," "Stimulating," "Convenient," "Comprehensive," and "liked viewing other people's posts" as shown in Table 5.

\section{CONCLUSIONS}

This study's findings confirm that interaction through a carefully designed website can facilitate reflective learning among students regardless of the institution type (i.e., a four-year public university, a four-year private university, or a community college). In addition, this type of interactive online space is a best practice for online education as it provides a viable means for students to interact, identify as equals, personalize their spaces, and lengthen their deliberative processes with academic reflectivity. End-of-semester surveys confirm the pedagogical benefits of interactions such as these, with over half of the students (65\%) saying they visited the website to interact with others beyond semester syllabi requirements.

The research here focused on differing institution types and is relevant for decision makers across a variety of fields and, in particular, professors designing educationally vigorous courses and policy makers and university administrators addressing 


\begin{tabular}{|c|c|}
\hline What did you think about the collaboration? & $\begin{array}{l}\text { Provide a one or few word reaction to the } \\
\text { collaboration. }\end{array}$ \\
\hline $\begin{array}{l}\text { I enjoyed learning new things but also being able to participate in how my peers view politics. } \\
\text { That we all have more in common than we think. Being in a different political party than someone else } \\
\text { doesn't necessarily mean we have different values. } \\
\text { To be more open to listening to opposing opinions. } \\
\text { It was fun interacting with students from another state and also classmates to discuss issues. The } \\
\text { website was very interactive. } \\
\text { I learned that a lot of people have interesting things about politics. } \\
\text { I learned a lot of things that had at first sounded boring but once I actually took the time to read and } \\
\text { study them they explained a lot. For example, voting and primaries or the U.S. constitution. } \\
\text { As an international student... the discussions were very helpful in applying what we learned in class to } \\
\text { real life. } \\
\text { I do not follow politics as much as I should but participating in the Ning group made politics more } \\
\text { interesting. Hearing everyone's point of view on the various topics was very enlightening. } \\
\text { I learned that different students think the same about politics ... but it was interesting to hear and gain } \\
\text { knowledge about it. I know I might not pass but I will retake and give more to it. } \\
\text { To be more open to listening to opposing opinions. } \\
\text { Other people's opinions were very intriguing ... educational. }\end{array}$ & $\begin{array}{l}\text { How important politics are in my life. } \\
\text { Other people's opinions were very intriguing } \\
\text { Very interesting } \\
\text { Very simple } \\
\text { Different and Excellent } \\
\text { mind opening } \\
\text { Myspace } \\
\text { interactive } \\
\text { Eye-opening } \\
\text { Fun, confusing } \\
\text { Brilliant } \\
\text { Great experience } \\
\text { really different } \\
\text { interesting } \\
\text { Stimulating; different } \\
\text { Convenient, Comprehensive } \\
\text { Iliked viewing other people's opinions }\end{array}$ \\
\hline
\end{tabular}

\begin{tabular}{|l|l|}
\hline \multicolumn{2}{|l|}{ Table 6. Comparing Chickering \& Gamson's (1987) Seven Principles with Online Best Principles } \\
\hline \multicolumn{1}{|c|}{ Chickering \& Gamson's best practices } & \multicolumn{1}{c|}{ Online best principles } \\
\hline 1. Encourages student-peer contact & $\begin{array}{l}\text { Contact inside and out the classroom increases student motivation and involvement. } \\
\text { Contact enhances their intellectual commitment and encourages them to think about their own learning } \\
\text { and future plans. }\end{array}$ \\
\hline 2. Encourages cooperation among students & $\begin{array}{l}\text { Learning is more of a team/collaborative effort than being solo. } \\
\text { Sharing ideas and responding to others' reactions improves thinking and deepens understanding. }\end{array}$ \\
\hline 3. Encourages active learning & $\begin{array}{l}\text { Leaning is enhanced as active learning is a continuous dialogue and students continually learn. } \\
\text { In writing about it, relating it to their experiences, and applying it to their daily lives, active learning is } \\
\text { continuously encouraged. }\end{array}$ \\
\hline $\begin{array}{l}\text { 4. Gives prompt feedback } \\
\text { 5. Emphasizes time on task }\end{array}$ & $\begin{array}{l}\text { Student peer feedback emphasizes learning. They have greater chances to reflect on what they have } \\
\text { learned, what they still need to know, and, with an emphasis on the task at hand, assess themselves from } \\
\text { multiple perspectives. }\end{array}$ \\
\hline $\begin{array}{l}\text { 6. Communicates high expectations } \\
\text { 7. Respects diverse talents and ways of } \\
\text { learning }\end{array}$ & $\begin{array}{l}\text { Deliberations continuously provide communication day or night. They provide for a diversity of opinions. } \\
\text { While students' experiences are different, they are common as well in relating to others and providing } \\
\text { flexibility of learning. }\end{array}$ \\
\hline
\end{tabular}


the changing nature of their student clientele. At a time when university resources and the demands upon staff are increasing, online deliberations offer students the opportunity to learn by personalizing their experiences. These asynchronous online interactions also give students more time for reflective thinking, and they often take greater responsibility for their own learning. Similarly, other studies offer support for the pedagogical benefits that online deliberative strategies provide. Specifically, a researcher reported greater learning with higher levels of student peer connections among graduate students (Holzweiss et al., 2014) while another researcher found that students learn more when interacting with each other than when they are recipients of face-to-face instruction (Cross, 1987).

This research is also significant for educators in general. Online peer deliberative strategies can be applied across a variety of disciplines and class types, whether they are face-to-face, hybrid, or online, with national and international reach. They can also be used in comparable courses such as English, math, social science, medicine, or engineering, thus creating a highly effective and robust extended classroom. The benefits of incorporating peer deliberations in any discipline include increasing academic achievement, increasing student confidence and self-esteem, and enhancing peer relations. These wide-ranging benefits of online interactions are in line with Chickering and Gamson's (1987) seven principles for good practice in undergraduate education as they encourage student-peer cooperation and contact, active learning, respect and diversity of opinions, and different ways of learning, as shown in Table 6.

There is still a pressing need for educators to adopt interactive teaching methods such as the deliberative online format presented in this study. There are a number of positive outcomes and/or benefits of online deliberations. In particular, they can:

- provide students opportunities to exercise reflective critical thinking strategies;

- engage students with others outside their geographic boundaries;

- teach students to evaluate how issues impact others in similar and dissimilar ways;

- help refine crucial thought in written communication;

- teach students to question and pursue the root significance of questions;

- provide a holistic teaching and learning experience;

- provide opportunities for giving/receiving feedback that reflects on differing points of view;

- teach students to analyze and/or evaluate arguments, interpretations, beliefs, or theories;

- promote team work;

- prepare students for work in or outside of academia;

- expose students to differing perspectives;

- promote thought-provoking communication or consensus building; and

- provide a forum for students to explain their ideas to others as they learn and test their own learning (Boud et al., 2001).

Education programs that adopt deliberative methods as their guiding framework will provide a space for students to identify with others in dissimilar and similar positions while thinking critically about their own perspectives, as prior researchers have noted (Boud et al., 2001; Chadha, 2017a; Paul \& Elder, 2012). With enhanced deliberative-based learning comes confidence in self-expression, knowledge of issues, the ability to confirm personalized experiences, civility between people with different views, and political conviction. In addition, more research is needed in instructional education with regard to how students learn online, especially because there were no significant differences among students participating across any institution type. 


\section{REFERENCES}

Allen, I. E., \& Seaman, J. (2015). Grade level: Tracking online education in the United States. Babson Park, MA: Babson Survey Research Group.

Baek, Y. M., Wojcieszak, M., \& Delli Carpini, M. X. (2012). Online versus face-to-face deliberation: Who? Why? What? With what effects? New Media \& Society, 14(3), 363-383. doi:10.1177/1461444811413191

Bixler, B. A. (2007). The effects of scaffolding student's problem-solving process via question prompts on problem solving and intrinsic motivation in an online learning environment(Doctoral dissertation, The Pennsylvania State University). Retrieved from https://etda.libraries.psu.edu/ catalog/7748

Boud, D., Cohen, R., \& Sampson, J. (2001). Peer learning in higher education: Learning from and with each other. London, UK: Stylus Publishing Inc.

Boud, D., Cohen, R., \& Sampson, J. (Eds.). (2014). Peer learning in higher education: Learning from and with each other. [Place of publication not identified]: Routledge.

Bozanta, A., \& Mardikyan, S. (2017). The effects of social media use on collaborative learning: A case of Turkey. Turkish Online Journal of Distance Education, 18(1), 96-110.

Bukovchik, R., Van Vechten, R. B., \& Chadha, A. (2013). How students talk to each other: Findings from an academic social networking project. In A. R. M. McCartney, E. A. Bennion, D. W. Simpson (Eds.). Teaching civic engagement: From student to active citizen (pp. 167-188). Washington, DC: American Political Science Association.

Caspi, A., Chajut, E., \& Saporta, K. (2008). Participation in class and in online discussions: Gender differences. Computers \& Education, 50, 718-724. doi:10.1016/j.compedu.2006.08.003

Chadha, A. (2017a) Learning to learn: Lessons from a collaboration. Journal of Scholarship of Teaching and Learning, 17(3), 34-47. doi:10.14434/josotl.v17i3.21431

Chadha, A. (2017b). Comparing student reflectiveness in online discussion forums across modes of instruction and levels of courses. Journal of Educators Online, 14(2).

Chadha, A. (2017c) E-learning opens doors to the online community: Lessons from a longitudinal study. National Social Science Association, 48(2), 45-52.

Chang, M. M. (2007). Enhancing Web-based language learning through self-monitoring. Journal of Computer Assisted Learning, 23(3), 187-196. doi:10.1111/j.13652729.2006.00203.x
Chickering, A. W., \& Gamson, Z. F. (1987). Seven principles for good practice in undergraduate education. AAHE bulletin, (March), 3-7.

Cho, J., Ahmed, S., Keum, H., Choi, Y. J., \& Lee, J. H. (2018). Influencing myself: Self-reinforcement through online political expression. Communication Research, 45(1), 83-111. doi:10.1177/0093650216644020

Chu, S. K., Capio, C. M., van Aalst, J. C., \& Cheng, E. W. (2017). Evaluating the use of a social media tool for collaborative group writing of secondary school students in Hong Kong. Computers \& Education, 110, 170-180. doi:10.1016/j. compedu.2017.03.006

Chung, S., \& Han, I. (2013). Factors influencing information distortion in online deliberations: The effects of informational characteristics and regulatory focus. Computers in Human Behavior, 29(6), 2188-2196. doi:10.1016/j.chb.2013.04.036

Chung, S., Chung, M. J., \& Severance, C. (1999). Design of support tools and knowledge building in a virtual university course: Effect of reflection and self-explanation prompts. Paper presented at the Web Net 99 World Conference on the WWW and Internet Proceedings, Honolulu, Hawaii. (ERIC Document Reproduction Service No. ED448706).

Cole, M. T., Shelley, D. J., \& Swartz, L. B. (2014). Online instruction, e-learning, and student satisfaction: A three year study. The International Review of Research in Open and Distributed Learning, 15(6). doi.org/10.19173/irrodl.v15i6.1748

Conrad, R. M., \& Donaldson, J. A. (2004). Engaging the online learner: Activities and resources for creative instruction. San Francisco, CA: John Wiley \& Sons, Inc.

Cook, D. A., Dupras, D. M., Thompson, W. G., \& Pankratz, V. S. (2005). Web-based learning in residents' continuity clinics: A randomized, controlled trial. Academic Medicine, 80(1), 90-97.

Crippen, K. J., \& Earl, B. L. (2007). The impact of web-based worked examples and self-explanation on performance, problem solving, and self-efficacy. Computers \& Education, 49(3), 809-821. doi:10.1016/j.compedu.2005.11.018

Cross, P. (1987). Teaching for learning. AAHE Bulletin, 39(8), 3-7.

Dayton, D., \& Vaughn, M. (2007). Developing a quality assurance process to guide the design and assessment of online courses. Technical Communication, 54(4), 475-489.

Dixson, M. D. (2010). Creating effective student engagement in online courses: What do students find engaging? Journal of the Scholarship of Teaching and Learning, 10(2), 1-13. 
Ellis, R. A., Goodyear, P., Prosser, M., \& O'Hara, A. (2006). How and what university students learn through online and faceto-face discussion: Conceptions, intentions and approaches. Journal of Computer Assisted Learning, 22(4), 244-256. doi:10.1111/j.1365-2729.2006.00173.x

Englund, T. (2006). Deliberative communication: A pragmatist proposal. Journal of Curriculum Studies, 38(5), 503-520. doi:10.1080/00220270600670775

Eom, S. B., \& Ashill, N. (2016). The determinants of students' perceived learning outcomes and satisfaction in university online education: An update. Decision Sciences Journal of Innovative Education, 14(2), 185-215. doi:10.1111/dsji.12097

Evans, S., Steele, J., Robertson, S., \& Dyer, T. (2017). Personalizing post titles in the online classroom: A best practice? Journal of Educators Online, 14(2).

Eveland, W. P., Shah, D. V., \& Kwak, N. (2003). Assessing causality in the cognitive mediation model: A panel study of motivation, information processing, and learning during Campaign 2000. Communication Research, 30(4), 359-386. doi:10.1177/0093650203253369

Faraj, S., Jarvenpaa, S. L., \& Majchrzak, A. (2011). Knowledge collaboration in online communities. Organization science, 22(5), 1224-1239. doi:10.1287/orsc.1100.0614

Farinella, A., Hobbs, K., \& Weeks, H. (2000). Distance delivery: The faculty perspective. Financial Practice and Education, 10(1), 184-194.

Garrison, D. R., Anderson, T., \& Archer, W. (2003). A theory of critical inquiry in online distance education. In M. Moore and G. Anderson (Eds.), Handbook of distance education (pp. 113-127). New York, NY: Erlbaum.

Gayton, J., \& McEwen, B. C. (2007). Effective online instructional and assessment strategies. The American Journal of Distance Education, 21(3), 117-132. doi:10.1080/08923640701341653

Graddol, D., \& J. Swann. (1989). Gender voices. Oxford, UK: Basil Blackwell.

Gurin, P., Nagda, B. R. A., \& Lopez, G. E. (2004). The benefits of diversity in education for democratic citizenship. Journal of Social Issues, 60(1), 17-34. doi:10.1111/j.00224537.2004.00097.x

Guttman, A. (2000). Why should schools care about civic education? In L. McDonnell, P. M. Timpane, \& R. Bejamin (Eds.), Rediscovering the democratic purposes of education (pp. 571-572). Lawrence, KS: University Press of Kansas.

Hake, R. R. (1998). Interactive-engagement versus traditional methods: A six-thousand-student survey of mechanics test data for introductory physics courses. American Journal of Physics, 66(1), 64-74. doi:10.1119/1.18809
Hamann, K., Pollock, P. H., \& Wilson, B. M. (2009). Learning from "listening" to peers in online Political Science classes. Journal of Political Science Education, 5(1), 1-11. doi:1080/15512160802612011

Hardy, B. W., \& Scheufele, D. A. (2002). Examining differential gains from Internet use: Comparing the moderating role of talk and online interactions. Journal of Communication, 55(1), 71-84. doi:10.1111/j.1460-2466.2005.tb02659.x

Herring, S. (1993). Gender and democracy in computer-mediated communication. Electronic Journal of Communication, 3(2), 3-31.

Hostetter, C., \& Busch, M. (2013). Community matters: Social presence and learning outcomes. Journal of the Scholarship of Teaching and Learning, 13(1), 77-86.

Jaggars, S. S. (2014). Choosing between online and face-to-face courses: Community college student voices. American Journal of Distance Education, 28(1), 27-38.

Kehrwald, B. A. (2008). Understanding social presence in text based online learning environments. Distance Education, 1(29), 89-106. doi:10.1080/01587910802004860

Kenski, K., \& Stroud, N. J. (2006). Connections between Internet use and political efficacy, knowledge, and participation. Journal of Broadcasting and Electronic Media, 50(2), 173-192. doi:10.1207/s15506878jobem5002_1

Keramidas, C. G. (2012). Are undergraduate students ready for online learning? A comparison of online and face-to-face sections of a course. Rural Special Education Quarterly, 31(4), 25-32. doi:10.1177/875687051203100405

Kiesler, S., Siegel, J., \& McGuire, T. W. (1984). Social psychological aspects of computer-mediated communication. American Psychologist, 39(10), 1123.

Levy, Y. (2008). An empirical development of critical value factors (CVF) of online learning activities: An application of activity theory and cognitive value theory. Computers \& Education, 51(4), 1664-1675. doi:10.1016/j.compedu.2008.04.003

Lou, Y., Abrami, P. C., \& d'Apollonia, S. (2001). Small group and individual learning with technology: A meta-analysis. Review of Educational Research, 71(3), 449-521. doi:10.3102/00346543071003449

Mandernach, B. J. (2009). Effect of instructor-personalized multimedia in the online classroom. The International Review of Research in Open and Distributed Learning, 10(3).

Merryfield, M. (2001). The paradoxes of teaching multicultural education course online. Journal of Teacher Education, 52(4), 52(4), 283-299. doi:10.1177/0022487101052004003 
Meyer, A. (2003). Face-to-face versus threaded discussions: The role of time and higher-order thinking. Journal of Asynchronous Learning Networks, 7(3), 55-65.

Mooney Simmie, G., \& Lang, M. (2018). Deliberative teacher education beyond boundaries: discursive practices for eliciting gender awareness. Teachers and Teaching, 24(2), 135-150. doi:10.1080/13540602.2017.1370420

Moy, P., \& Gastil, J. (2006). Predicting deliberative conversation: The impact of discussion networks, media use, and political cognitions. Political Communication, 23(4), 443-460. doi:10.1080/10584600600977003

Newlin, H., \& Wang, Y. (2002). Integrating technology and pedagogy: Web instruction and seven principles of undergraduate education. Teaching of Psychology, 29(4), 325-330. doi:10.1207/S15328023TOP2904_15

Pamental, M. (1998). What is it like to be a Deliberative Democrat? Philosophy of Education Archive, 222-230. Retrieved from https://ojs.education.illinois.edu/index.php/pes/article/view/2110

Pape, L. (2010). Blended teaching and learning. The Education Digest, 76(2), 22.

Pappas, C. (2014). Instructional design models and theories: Cooperative and collaborative theory. Retrieved from https:// elearningindustry.com/cooperative-and-collaborative-theory

Paul, R., \& Elder, L. (2012). Critical thinking: Tools for taking charge of your learning and tour life. Dillion Beach, CA: Prentice Hall Publishing.

Pollock, P. H., Hamann, K., \& Wilson, B. M. (2011). Learning through discussions: Comparing the benefits of smallgroup and large-class settings. Journal of Political Science Education, 7(1), 48-64. doi:10.1080/15512169.2011.539913

Pukdesree, S. (2017). The comparative study of collaborative learning and SDLC Model to develop IT group projects. Tem Journal-Technology Education Management Informatics, 6(4), 800-809. doi:10.18421/TEM64-20

Roblyer, M. D., \& Wiencke, W. R. (2004). Exploring the interaction equation: Validating a rubric to assess and encourage interaction in distance courses. Journal of Asynchronous Learning Networks, 8(4). Retrieved from http://www.sloan-c. org/publications/jaln/v8n4/v8n4_roblyer.asp

Rountree, D. (1995). Teaching and learning online: A correspondence education for the 21st century? British Journal of Educational Technology, 26, 205-215. doi:10.1111/j.1467-8535.1995.

Rovai, A., \& Baker, J. D. (2005). Gender differences in online learning: Sense of community, perceived learning, and interpersonal interactions. Quarterly Review of Distance
Education, 6(1), 31-44.

Russell, T. L. (1999). The no significant difference phenomenon: A comparative research annotated bibliography on technology for distance education. Raleigh, NC: North Carolina State University.

Saito, H., \& Miwa, K. (2007). Construction of a learning environment supporting learners' reflection: A case of information seeking on the Web. Computers \& Education, 49(2), 214-229. doi:10.1016/j.compedu.2005.07.001

Saunders, W. L. (1992). The constructivist perspective: Implications and teaching strategies for science. School Science and Mathematics, 92(3), 136-141. doi:10.1111/j.1949-8594.1992. tb12159.x

Schwartz, T. A. (2014). Flipping the statistics classroom in nursing education. Journal of Nursing Education, 53(4):199-206. doi:10.3928/01484834-20140325-02

Shen, P. D., Lee, T. H., \& Tsai, C. W. (2007). Applying web-enabled problem-based learning and self-regulated learning to enhance computing skills of Taiwan's vocational students: A quasi-experimental study of a short-term module. Electronic Journal of e-Learning, 5(2), 147-156.

Stitzlein, M. (2010). Deliberative democracy in teacher education, Journal of Public Deliberation, 6(1), Article 5. Retrieved from http://www.publicdeliberation.net/jpd/vol6/iss1/art5

Swan, K. (2002). Building learning communities in online courses: The importance of interaction. Education, Communication \& Information, 2(1), 23-49. doi:10.1080/1463631022000005016

Topping, K. J. (1996). The effectiveness of peer tutoring in further and higher education: A typology and review of the literature. Higher Education, 32(3), 321-345. doi:10.1007/BF00138870

Wang, K. H., Wang, T. H., Wang, W. L., \& Huang, S. C. (2006). Learning styles and formative assessment strategy: Enhancing student achievement in Web-based learning. Journal of Computer Assisted Learning, 22(3), 207-217. doi:10.1111/j.1365-2729.2006.00166.x

Wickersham, L. E., \& Dooley, K. E. (2006). A content analysis of critical thinking skills as an indicator of quality of online discussion in virtual learning communities. Quarterly Review of Distance Education, 7(2), 185-193.

Wilson, B. M., Pollock, P. H., \& Hamann, K. (2007). Does active learning enhance learner outcomes? Evidence from discussion participation in online classes. Journal of Political Science Education, 3(2), 131-142. Allen, E. I., \& Seaman, J. (2011). Going the distance: Online education in the United States. Retrieved from http://www.onlinelearningsurvey.com/ reports/goingthedistance.pdf 
Wladis, C., Conway, K. M., \& Hachey, A. C. (2015). The online STEM classroom-Who succeeds? An exploration of the impact of ethnicity, gender, and non-traditional student characteristics in the community college context. Community College Review, 43(2), 142-164. doi:10.1177/0091552115571729

Wolfe, J. (2000). Gender, ethnicity, and classroom discourse. Written Communication, 17(4), 491-519. doi:10.1177/0741088300017004003

Yoo, S. J., \& Huang, W. D. (2013). Engaging online adult learners in higher education: Motivational factors impacted by gender, age, and prior experiences. The Journal of Continuing Higher Education, 61(3), 151-164. doi:10.1080/07377363.2013.8368 23

Zúñiga, X., Williams, E. A., \& Berger, J. B. (2005). Action-oriented democratic outcomes: The impact of student involvement with campus diversity. Journal of College Student Development, 46(6), 660-678. 